\title{
Conspectus
}

\section{A Gentleman and a Scholar}

\section{A Tribute to Edward Lane Davis}

\section{J ohn S. Nelson}

Poroi, 3, 2, December, 2004

1 It is time for a little tutorial on ethos. A word tour, this is not, for the neighboring terms get too little attention. But even in broad outline, few words can have more telling careers than ethos, and it is under the aegis of ethos that this issue of Poroi comes together.

2 Ethos was the word in ancient Greek for character. This classical kind of character is rhetorical and public rather than psychological and internal, as was character for the Victorians. Classical ethos is the standing of the speaker for the audience. Not just any old audience is at issue, but specifically a classical public, where the members take full parts in collaborating to manage the commonwealth. The classical public is oratorical, not dialogical; still the members take turns in speaking and acting at center stage. In the ancient sense, therefore, ethos is who somebody is in speech in action in public - as told by an audience experienced in many of the same politics. ${ }^{1}$ The specific identities of classical characters stay alive for their publics in stories that judge the virtues and vices while suggesting how people should act toward each other: the province of what we call ethics. ${ }^{2}$

3 This explains how Aristotle could recognize ethos as a legitimate mode of persuasion comparable to logos as logic and pathos as mobilization of emotions. ${ }^{3}$ The ancient emphasis on virtue in character might well have made ethos as important as either logos or pathos in classical persuasion. To know from sustained interaction the character who advances some claim can be to know an enormous amount about what to make of it.

4 Yet classical publics are too small and intimate for modern polities. The invention of civil society gradually turns participation away from government. It also truncates oratorical voices into electoral votes. Especially it shrinks classical ethos to modern credentials or, at most, credibility. Alasdair MacIntyre has lamented how the seventeenth and eighteenth centuries put all diverse, plural virtues into a singular template of virtue. ${ }^{4}$ That led 
later to commensurating all values on a single scale of pain to pleasure or of cost to benefit. It enabled the conceit of cashing out any deed in dollars and cents. Credentials make storied, fullbodied characters into lists of offices held and awards won. Likewise credibility collapses the myriad dimensions of classical ethos into one. It regresses them onto a single spectrum that stretches incrementally from doubt to belief: not much character or many relationships left there.

5 A funny thing happened, however, on the way to the cashier. Our postmodern world has recuperated the older ethos and expanded it to whole settings or situations. Now ethos in English means the encompassing tone for a setting, the pervasive spirit of a situation. Postmodern ethos is the diffuse but often decisive character of a condition. It is the atmosphere, the esprit de corps, the mood. ${ }^{5}$

6 Science fiction, an epitome of postmodern literature, clarifies the concept by taking it to an extreme. SF often treats planets, polities, ecologies, and other kinds of settings as coherent, even sentient characters. ${ }^{6}$ Beautiful cases in point are Frank Herbert's Dune, Ursula Le Guin's “Vaster Than Empires and More Slow,” and Stanislaw Lem's Solaris.7 In these stories, the ethos is the protagonist. Not only does the permeating atmosphere inspirit the stage, it is the stage and even sets it(self). Indeed the postmodern ethos sometimes drives the action in exactly the agonal mode of the classical Greeks. In the initial Dune trilogy, the title planet becomes a tragic figure in the Greek sense: a hero whose characteristic virtue proves its fateful vice. ${ }^{8}$

7 Nor does the political relevance of postmodern ethos end with science fiction. In fact, as scholars of public opinion have insisted in effect for half a century, even though they do not use the term, postmodern ethos joins earlier versions of argument by public character in proving pivotal for various acts of persuasion. Especially this dominates the disseminated politics of postmodern democracies.9 ${ }^{9}$ But we also can see it operating in polities that reach from ancient Greece to current Iran. Enter the articles for the present issue.

\section{Contents}

8 Each of the essays in this fifth offering of Poroi concerns ethos, especially in the politics of war and education. Different variants of ethos are involved, and sometimes the concern stays mostly in 
the subtext, but it is prominent nonetheless.

9 Glenn Perusek analyzes "Strategy and Changing Moods in Thucydides." Perusek follows Pericles and other figures from the Peloponnesian War in moving between public characters and public moods. Hence he combines a close reading of appeals to classical ethos with an argument about the importance of manipulating the larger ethoi of armies, navies, publics, and polities. In the account of Thucydides, shows Perusek, moods are crucial rhetorically for political strategies.

10 War is also the exigency for Samuel A. Chambers and Daniel Williford in addressing "Anti-Imperialism in the Buffyverse." Theirs is the classical (ethos) interest in public character. Mindful of the American imperialism at work in the war in Iraq, Chambers and Willford take issue with an earlier Poroi comparison of George Bush and Donald Rumsfeld to vampire killers. Drawing on the television version of Buffy the Vampire Slayer, this has Chambers and Williford "Challenging the Mythos of Bush as Vampire Slayer." Hence theirs is the journal's second myth scape, somewhat in rebuttal to the first.

11 Education in Iranian conditions akin to totalitarian furnish Alfonso Damico with a test case for treating "Liberalism and Culturism as Interrogatories." Do we owe equal respect to all forms of life, as culturists maintain? The liberal such as J ohn Dewey or J ohn Stuart Mill might like to say so but concludes not. Damico argues that this can make the two species of politics valuable, if occasionally vehement, critics of each other. He defends liberalism by the ethos strategy of analyzing the character and setting of Azar Nafisi when she tries for a tiny, partial, sputtering public among graduate students who are Reading Lolita in Tehran. ${ }^{10}$

12 Education in entertainment conditions tied to marketing provide J oanna Ploeger with a platform for elucidating "TechnoScientific Spectacle" as "The Rhetoric of IMAX in the Contemporary Science Museum." Ploeger analyzes the audiovisual rhetoric of Yellowstone to explain how IMAX movies inflect the postmodern ethos of science centers and museums. These vehicles were invented to engage larger publics in scientific inquiries and controversies. Yet she argues that they are sliding instead toward spectacles that keep audiences passive and uninvolved in the creation action or critical thought crucial for science. 
13 Pathos is the title topic in "The Passion of the Film," yet the analysis soon extends to the postmodern ethos generated by the movie phenomenon of the year. The approach is to consider the most famous and profitable film from 2004 as an exercise in experiential persuasion. ${ }^{11}$ The argument is that The Passion of the Christ keeps surprising company with apparent contrasts such as The Day After Tomorrow (2004), Saving Private Ryan (1998), and especially Se7en (1996). All use devices of ethos, logos, pathos, mythos, tropos, and more to give viewers such keen, fullbodied senses of situations that are, for us, little known and hard to experience. These films help us feel our way so vividly through their situations that the experiences oblige us to act differently from before.

14 Let me add that this is Poroi's first film take. It means that the journal has now published at least one example for each of its occasional features. Henceforth all you potential contributors of film takes (or word tours or rhetorical inventions or other features) can work through the republican-rhetorical mode of imitatio - as well as the modern technical devices of instruction. So don't be bashful...

\section{Exemplars}

15 This journal springs from a movement in scholarship known in some quarters as rhetoric of inquiry. Another result of the movement has been an interdisciplinary field that comprehends and improves inquiry through the many distinctive devices from rhetoric. The rhetoric comes in many versions: classical, modern, postmodern, and more. Whatever the inspiration, rhetoric of inquiry respects fields, disciplines, and universities as communities of inquiry. ${ }^{12}$ They sustain for scholars the plural and partial publics especially familiar in our postmodern settings. ${ }^{13}$ Yet these publics, too, are places where participants become memorable characters. And this month, one of the most vivid and virtuous has passed from our scene. We do well to tell his story.

16 "Though direct moral teaching does much," wrote J ohn Stuart Mill, "indirect does more."14 Of his teacher, who was his father, Mill added that his "effect... . on my character, did not depend solely on what he said or did with that direct object, but also, and still more, on what manner of man he was."15 So by embodiment and action even more than by classroom instruction, Edward Lane Davis taught politics and virtue to generations of Iowa students, 
faculty, and friends.

17 Lane Davis would be remembered by us more for his beginning in Oak Grove of Alabama than for his birth in Manchester of New Hampshire. More for his vigorous practice and support of Iowa athletics in sailing, wrestling, football, baseball, basketball, and track-and-field than for his courageous resistance to the Parkinson's disease that took his strength and eventually his life. More for his teaching of political theory in Literature, Science, and the Arts; the Good Society, Honors, and Unified Programs; and Political Science at the Universities of Iowa, Washington, and Wisconsin than for his writing on pluralism and jurisprudence or his telling of stories. Especially Lane would want to be remembered more for his enduring love of Sue Davis, their three sons, Chris, Evan, and Andy, their dear grandchildren and other relatives, as well as their many, many friends than even for his passionate positions on everything from politics and culture to the kitchen sink. Lane never met a topic he was unwilling to contest.

18 Lane was, in his own words, "a gentleman and a scholar." He learned the mantra from a mentor in graduate school; he earned the moniker from a lifetime of virtue in action and curiosity of intellect. Always he emphasized keeping priorities straight, and he would tell you that the order matters: he was a gentleman first and a scholar second, choosing perfection of the life in support of others over perfection of the work in service to self.

19 As a gentleman, Lane combined the charm of the South, the salt of the Northeast, the pepper of Kansas, and the friendly concern of the Midwest. His code of honor came equally from these sources and from his remarkable connections with institutions such as this church and the University of Iowa. All these components and more made him a man memorable for students, colleagues, and acquaintances.

20 Even passing you in the hall, Lane would beam and greet you with such striking enthusiasm that your spirits would leap upward for hours. His two eyes would lock onto yours with lively attention. Then his two hands, strong from sailing and warm with friendship, would engulf your one - raising it vigorously up and down, pumping into you the good energy of human regard. The journalist J oe Klein argues that "the handshake is the threshold act, the beginning of politics."16 Especially this holds, I think, for the modern politics of contract, running from the Renaissance and the Reformation to the present period. These are the politics that 
Lane taught most often; and in them, the kind of handshake is the character of the gentleman. Like his handshake, Lane was a gentleman of passion, kindness, encompassing intellect, and care for all issues great or small, unsettled or unsettling.

21 Ever analytical as political theorists, Lane and I talked intermittently for years about the cultures and components of the gentleman: when and where this character had arisen; what his virtues and vices, advantages and disadvantages might be; how and why he seems to have been disappearing from our scenes. We never talked about Lane as the epitome of the late-modern gentleman, but so he became to me, and I'd bet he suspected as much. Like others among his friends, I had learned that Lane could be most gracious about compliments as well as criticisms, but that he much preferred argument to admiration.

22 So we would argue. Ours were rollicking, free-for-all arguments about nearly everything under the sun. We conducted a decade of graduate seminars by arguing back-and-forth on one issue after another - switching positions shamelessly, playfully, back-andforth along the way - and inviting each student into the fray. Lane delighted in butting argumentative heads with pretty much everybody in the intellectual or civic neighborhood. He enjoyed years of lunchtime debates with Vernon Van Dyke, Don J ohnson, Arthur Bonfield, Bob Boynton, and any number of others.

Admission to this august society of inveterate arguers has been a highlight of my life. Often have I thanked Lane for this; and, like Lane, often I have lamented its inevitable passing.

23 My first trip to Iowa City was to interview for a faculty job in Political Science. I was mightily impressed at the friendliness of Iowans when Lane and Sue brought me to their house for an extraordinarily warm and welcoming dinner. Yet the talk at dinner and afterward kept turning argumentative. I was alarmed to see how this was pushing all my buttons as an incorrigible debater from high school onward. Lane was activating my deeply ingrained disposition to specify ad nauseum the sixteen flaws in any idea on the table for discussion. Yes, I knew enough manners and job-seeking tips to recognize that I should not take the bait; but too often, I just couldn't help myself. I did not know enough to realize that Lane was testing for the qualities he most wanted in a colleague. I went back to the Iowa House that night thinking that I'd had all too good a time. I'd foolishly let myself get carried away by the fascinating questions and arguments tossed at me by these interesting Iowans. I'd never had a job interview before, I'd put 
pleasure before propriety, and no doubt I'd botched this one royally. But not so, evidently, and Lane later allowed as how it might have been a saving grace for my Iowa employment prospects that I'd shown some spirit in argument that night - trying, at least, to keep his verbal haymakers at bay by counterpunching for all I was worth.

24 Like honey to a bear, argument to Lane was about as sweet as life gets; and he was eager to paw through any number of stinging objections to enjoy it. The ancient Greeks appreciated argument as agon, where our deepest virtues and hardest realities clash inescapably with one another. The challenge for civilization in the west has been to make these potential troubles into productive contests. The Greeks were not naïve about outcomes. They sought glory, but they saw tragedy, and they knew the agony bursting from both. In response, they cultivated a fervent, finely tuned feeling for the agonizing beauty in debates, sports, politics, and comparable competitions well done. And they, like Lane, found the bear's share of this beauty in passionate participation.

25 Lane truly was the passionate participant: witness his life-long love of sports. Argument was sport for Lane, of course, and this figured into his abiding concern for politics. It also helps explain his growing conviction that the best political texts are the biographies and especially the autobiographies of politicians. These share with readers the experiences of politics as action and contest that slipped away from political science and abstract versions of political theory in the twentieth century. In this respect, I think he may have regarded as the culmination of a distinguished career in teaching his years of teaming with Sandy Barkan to have students analyze political biographies for their course on "The Experience of Politics." Lane's abiding, oh-soSouthern love of stories - of hear them and reading them and writing them and telling them - also testifies to his deep feeling for action - in politics and all other arenas. For Lane, thinking should spur action, and theory should serve practice.

26 Stolidly a democrat, against totalitarian powers of the Axis and the Soviet bloc, Lane found in story, argument, and teaching theories of politics the modes of practice that distinguished his adult life. Lane seemed to see even his World War II labors in the Army Air Corps less as the service it was to the country and the world than as the start of his education in bureaucracy. Lane loathed administrative arrangements of most kinds as misdirected modes of power that insistently prove themselves ineffective or even 
perverse. He resisted the spirit of his times by clinging to an old Underwood typewriter when Bob Boynton brought personal computing to Political Science at Iowa. And he did much the same by enacting a personal example of the scholarly gentleman, who short-circuits the bureaucratic apparatus of rules and administrative specialists to do himself what needs doing for students, colleagues, and causes at his university.

27 Ecclesiastes 3:22 says "that there is nothing better than that a man should enjoy his work, for that is his lot." And most days, at least, Lane loved his work as a university professor. He was a teacher's teacher, both literally and in the larger sense. In 1985, Lane earned the Amoco Senior Faculty Teaching Award, then Iowa's highest honor for professional work in and beyond the classroom. He was a precise yet also a demonstrative speaker. He generated lively discussions. He crafted exquisite lectures. He taught the craft of teaching, which is pervasively political, with great dedication and skill. Several of Lane's assistants for teaching left Iowa to win top teaching awards from their institutions. I came to Iowa never having taught a course of any kind, and there is no doubt that this showed all too prominently in my first efforts here. But Lane came to the rescue, and I began to learn immense amounts by team-teaching with him. The continuing education was so agreeable that I did this once or twice a year for more than a decade: meaning that my students, too, are deeply in Lane's debt.

28 Lane argued that the field of political theory stays closer to concerns of political action than does any other part of the academy. When my arrival led us to rethink the Iowa curriculum for political theory, Lane wanted it to begin with an "Introduction to Political Thought and Political Action," and so it does to this day. More than anything else, it was Lane's example that taught me how politics are principally talk. From the ancient Greeks and Romans onward, politics are primarily oral and aural, conducted largely by the mouth and the ear - even when we have pages of letters, reams of print, and googles of Web sites, many with political ads to play at the click of a mouse. Lane and I have liked David Bell's reformulation of Harold Lasswell's liberal definition for politics:

Politics is talk. An oversimplification, of course, but one that ultimately lies closer to the truth than definitions like "who gets what, when, how." 
"Getting" can be an intensely private affair; talk (ordinarily) involves others. Not by accident does the term Parliament stem from the French parler, to speak. But politics is more than "a government of talk," because government itself is too restrictive. Much non- or even anti-governmental talk is political nonetheless. Is all talk political? Perhaps. To the extent that talk affects others (and most talk does), it has by definition assumed political overtones. For politics must be concerned in the widest sense with how people affect each other. A suitable reformulation might be, politics: who talks with whom, when, how. ${ }^{17}$

Thus argument transpires in talk; and the agonal, argumentative dynamics of politics are where Lane himself excelled. W. H. Auden lamented, "Why must Growth rob us / of the infant's heavenly / power to bellow?"18 From the classroom to the conversation, it didn't exactly do that to Lane Davis. Particularly as a political theorist, Lane lived loud, even as he acted gently to affect the others around him.

29 A modern gentleman is a man of principle. For a modern gentleman, a principle is neither a scientific generalization nor a moral conviction. It does not conquer us and force its acceptance as a stubborn truth. It does not beguile us with a beauty that ignores the consequences. Nor does it confer some self-righteous sense of moral certainty. Instead the principles of the gentleman animate his life and shape his place in the world.

30 One of the inadvertent but impressive teachers of my college years was Wendell Berry, the environmental essayist and poet from Kentucky. ${ }^{19}$ In his poem about "The Sycamore," Berry evokes how a gentleman can stand tall as a tree in the practice of principle. He offers a beautiful definition of a principle as "an indwelling/ the same as itself, and greater, that I would be ruled by."20 The word tree derives from the same Anglo root as truth. As a principled gentleman and scholar, Lane has been a touchstone for truth, a model in argument, and a friend for life. His is an exceptional roster of virtues.

31 Lane's example and principles helped shape and energize me; and I know I am far from alone in this. Lane and Sue have been vigorous and virtuoso gardeners. Their flowers, and especially their roses, are glorious to smell and see. Walking their land in the 
summer and fall became for my wife Connie and me a virtual tour of Lane's "Sycamore" character: sunny yet hospitable with shade, lush and fragrant, filling every inch with color and vitality.

32 Lane's prime principle was liberty. As any political theorist would guess, this made J ohn Stuart Mill one of Lane's favorite writers. The early pages of Mill's landmark work On Liberty expresses Lane's own priority of liberty for our times.

The struggle between Liberty and Authority is the most conspicuous feature in the portions of history with which we are earliest familiar .... [T] he sole end for which mankind are warranted, individually or collectively, interfering with the liberty of action of any of their number, is . . . to prevent harm to others. His own good, either physical or moral, is not a sufficient warrant. . . . If all mankind minus one were of one opinion, and only one person were of the contrary opinion, mankind would be no more justified in silencing that one person, than he, if he had the power, would be justified in silencing mankind. ... [T] he peculiar evil of silencing the expression of an opinion is, that it is robbing the human race; posterity as well as the existing generation; those who dissent from the opinion, still more than those who hold it. If the opinion is right, they are deprived of the opportunity of exchanging error for truth: if wrong, they lose, what is almost as great a benefit, the clearer perception and livelier impression of truth, produced by its collision with error. ${ }^{21}$

The younger Mill is famous for moving liberty beyond the independence of a community from outside colonizing or inside tyrannizing. Mill defined liberty more as individual freedom, particularly in personal belief and speech. More than that, his take On Liberty is that freedom thrives only when we as individuals continually contest our opinions in argument.

33 Lane concurred, with emphasis. He used to speculate that students successful in his classes were benefitting from early arguments around the dinner table. All Lane's friends, I imagine, learned that dining and arguing were hard to keep separate around Lane. My children, now grown, but for whom Lane and Sue will always be more-than-honorary grandparents, may have learned the art of, shall we say, "lively conversation" as much from the 
Davises as from the Nelsons.

34 My daughter Anna is now following in some of Lane's footsteps, by working in graduate and law school on political theory and jurisprudence. She points out to me a passage where Mill evoked one of his personal and intellectual heroes, Charles Austin. She loves how these words from one of Lane's heroes, Mill, hold for one of hers, Lane:

He was a man who never failed to impress greatly those with whom he came in contact, even when their opinions were the very reverse of his. The impression he gave was that of boundless strength, together with talents which, combined with such apparent force of will and character, seemed capable of dominating the world. ... It is seldom that men produce so great an immediate effect by speech ... and he did this in no ordinary degree. He loved to strike, and even to startle. He knew that decision is the greatest element of effect, and he uttered his opinions with all the decision he could throw into them, never so well pleased as when he astonished any one by their audacity. ... All which he defended with such verve and vivacity, and carried off by a manner so agreeable as well as forcible, that he always either came off victor, or divided the honors of the field. ${ }^{22}$

She writes, "I can picture Lane in this description, arguing delightedly (and sometimes, contrarily) with my dad in the Davis living room."

35 Anna has it right: Lane was a committed, world-class contrarian in the most constructive and enjoyable sense of the term. This is Berry's meaning when he brands himself a contrarian: someone who thrives in going against the grain of public pieties. Playing with ideas and arguing opinions, Lane would romp through hours and hours of agonal talk. With keen empathy, quick imagination, and real eloquence, he would take positions just for the fun of provocation. Then he would turn in a moment, often marked only by a broad smile, to oppose them with even greater wit and enthusiasm.

36 In "The Contrariness of the Mad Farmer," Berry as styles himself with a similar grin, he declares: "I am done with apologies. If contrariness is my / inheritance and destiny, so be it. If it is my 
mission / to go in at exits and come out at entrances, so be it." Then he concludes: "Going against men, I have heard at times a deep harmony / thrumming in the mixture, and when they ask me what / I say I don't know. It is not the only or the easiest / way to come to the truth. It is one way."23 It is a way of theorizing I watched Lane use beautifully with his classes, graduate and undergraduate; his colleagues, young and old; and his acquaintances, close or casual.

37 Lane loved arguing against the conventionally wise or politically correct. Like Socrates, Lane did this more to provoke arguing and thinking than to persuade or edify in any mode more familiar from the polity or even the academy. Lane relished throwing spears at the sacred cows in politics, arts, sports, and almost everything else. For me, at least, Thomas J efferson embodies the gentleman farmer, Wendell Berry the contrarian farmer, and Lane Davis the contrarian gardener and gentleman - or I might also say the gentle contrarian: for Lane, both phrases fit.

38 Like Berry in his "Manifesto" for "The Mad Farmer Liberation Front," I can hear even now in my mind's ear how Lane, with a teasing and humble sense of self-contradiction, would urge us, in effect, to join the movement of contrarians:

So, friends, every day do something that won't compute. Love the Lord. Love the world. Work for nothing. Take all that you have and be poor. Love someone who does not deserve it. Denounce the government and embrace the flag. Hope to live in that free republic for which it stands.

Contrarians like Berry and Davis are apt to prove a liberal unto libertarian movement, I think, even if Mill moved in his later life more toward socialism. There is a contrarian love for being elusive, for escaping the public's conventions of character. Agonal characters can be deeper and more complicated than our usual types. They work at it.

As soon as the general and the politicos can predict the motions of your mind, lose it. Leave it as a sign to mark the false trail, the way 
you didn't go. Be like the fox

who makes more tracks than necessary, some in the wrong direction.

Practice resurrection. ${ }^{24}$

These are refreshing, resurrecting effects that Lane often had on me and his many other friends. By passion and by play, he goaded us into practicing our minds on issues that matter. Yet Lane had fun with the agon, whether in arguments or athletics, and he insisted that contests stay civil.

39 Lately our shared friend, the economist Deirdre McCloskey, has been writing books that confirm years of casual speculation by Lane and me. It explains how the modern gentleman begins as a man of bourgeois virtue and survives into our times as the bedrock of a genuinely civil society. ${ }^{25}$ As the historian Allan Megill, another shared friend from earlier days in Schaeffer Hall, remembers, Lane "was always a voice of true civilization at the University of Iowa."

40 Like me, Megill is one of many colleagues at Iowa and elsewhere graced by Lane with astute suggestions for improving their ideas and prose. Myriad faculty members and students would join Megill in praising Lane as a most "careful reader." And in the gardens of political theory cultivated by Lane, there is no higher praise. For many of us scholars, Lane demonstrated every day the genius and zest of western civilization. He was as well-read as anyone could want, ever up-to-date on controversies of the moment and contributions for the ages. And as a political theorist, Lane was ever eager to argue about how to make sense of these vast and varied issues through the political principles that could gentle our arguments, civilize our selves, and spur our actions.

41 As one of my favorite political theorists, Hannah Arendt, explained, principles inspirit. They animate us. As another, Robert Pirsig, insisted, principles give us energy, enthusiasm, passion. They move us to care. And oh, boy, did Lane Davis ever care! In Lane, as it should, principles produced passions. So Lane loved, or sometimes reviled, with passions so strong that they could startle the congenitally mild among us.

42 For years, Lane and I shared a kind of office alcove with four or five other faculty in Political Science at Iowa. Knowing Lane's goodness and gentlemanly self-restraint, I had to smile when his office would emit a loud exclamation: never too profane but still 
enough to get your attention. And even now I can laugh when remembering the sheer consternation of some faculty. They would peer cautiously out their open doors in that wing of Schaeffer Hall to see what was happening. But as a veteran, I knew already that the crash coming from Lane's office just meant that he had thrown another book across the room to whomp and rattle against the metal shelves. Usually, I would learn in time, this was simply a passionate act of exasperation. Lane just had to do something quick and physical about the bad understanding or worse prose exhibited in print by some colleague in the field. Later Gentleman Lane would be sheepish and apologetic about this, but he never retreated from caring enough about deeds or words to say and show vividly how he approved them - or not.

43 Lane agreed with Arendt that liberty in practice is action in public. Hence his passion for liberty was a passion for participation, and he passed the principle and the passion to students. Lane conducted some of the most engaging, participatory classes that Iowa or any other university is likely to see. Long before I arrived, Lane was being interviewed about his superlative teaching and educational philosophy. In one of the articles that resulted, we can be sure that the reporter got Lane's words right, because the resonance with Harry Truman is unmistakable: "I think [the university] should get students, grab them by the scruff of neck as freshmen, and say 'Look, damn it, you have got to participate!'”

44 By extension, Lane's passion for agonal participation reached well beyond ideas, classes, and politics. Lane excelled at sports as diverse as ping-pong and sailing. He helped create the UI Sailing Club; and every Labor Day, it still holds the Davis Regatta on Lake MacBride. When Lane could no sail no longer, he turned first to kayaks then to kites. When my son, Aaron, was young, Lane took the two of us to a wind-blown and wire-free hill at West High School to teach us the basics of kite-flying. Lane's zest was contagious for a time, and we bought kites of our own; but soon they were adorning walls at school and home. It just might be that few of us ordinary folks can equal Lane's joy in jousting with natural forces like wind and water.

45 Lane's fierce if gentlemanly passion for honorable contest turned even spectator sports into full-bodied participation. He brought as much energy, and more acumen, to cheering Hawkeye games as the athletes did to playing them. Lane was a great fan to sit beside in the stands. He could talk the history of the sport as well as the strategy on the field, preparations for the team along with 
performances on the court. He was a key benefactor for track and field in addition to sailing. But even better, to my athletically fevered way of thinking, was Lane's performance as a fan. To this day, I think that he might have been the only Iowan other than me to act adequately on the sage principle that cheering crowds need to yell for their basketball teams to rise up and turn the tide, rather than waiting for a player to do something worth applauding only after the fact.

46 Admittedly Lane and I might not have been great fans to sit behind in the stands. I do recall occasional, ever-so-polite requests to "Sit down in front!" It seems that less passionate Iowans could not stay seated and still see the action through the two bodies that kept jumping up to entreat the team to excellence. Sometimes I would turn with a smile to remind our critics ever so sweetly that they might as well stay at home to watch the game on TV if they did not want to stand up and cheer. How else could I help teach them how to support the team? Of course, Lane was too much the gentleman to join in this slightly aggressive repartee; but he did turn to me at times to add, "You tell 'em, J ohn!" If nothing else, this had a way of clearing space just behind us as the basketball season went deeper into winter, and I believe Lane was the one who observed that this might solve the problem of where to put our heavier coats.

47 Lane was a fine wit, a great fan, but a greater friend. If any virtue rivaled liberty in Lane's pantheon and practice, it was loyalty. For Lane, the loyalty of friendship was the code and mark of the gentleman. When he taught Plato's Republic on the disputed meaning of justice, Lane took the conventionally discredited side of Polemarchos rather than siding with Plato's hero of Socrates. Of course, as Lane was wont to notice, neither Socrates nor Plato was much of a gentleman. By contrarian but gentlemanly conviction, Lane loved the Polemarchos doctrine that "J ustice is to help your friends and hurt your enemies." Lane himself was willing on Christian principle to absorb harms far more than return them, but he knew that standing by friends in a contentious world means offending their enemies, and he had no hesitation about coming to the aid of anyone within the wide horizons of his personal affection. Lane was always liberal with his friends. He helped us left and right, up and down. He looked past our manifest faults to focus on our nascent graces. He made us much better than we otherwise would be.

48 If the quality of a scholar may be measured by the quality of his students, the performance of Lane Davis as a professor has set a 
high bar for the American academy. If the quality of a gentleman may be measured by the quality of his friends, the people gathered here in his honor and mindful of him from afar show that Lane has set a high bar for humanity as well. Toward the end of his life, Auden wrote, as one of Arendt's best friends: "None of us are as young/ as we were. So what? / Friendship never ages."26 The friend might die but never really leaves us. Lane Davis, the passionate epitome of a gentleman and a scholar was, is, and will be our friend.

(C) J ohn S. Nelson, 2004.

\section{Notes}

1 See J ohn S. Nelson, "Commerce among the Archipelagos: Rhetoric of Inquiry as a Practice of Coherent Education," The Core and the Canon: A National Debate, L. Robert Stevens, G. L. Seligmann, and J ulian Long, eds., Denton, TX, University of North Texas Press, 1993, pp. 78-100.

2 See J ohn S. Nelson, Tropes of Politics, Madison, University of Wisconsin Press, 1998, pp. 138-139,

$3 \quad$ Ibid., pp. 139-143.

4 See Alasdair MacIntyre, After Virtue, Notre Dame, IN, University of Notre Dame Press, (1981), 2d ed., 1984.

5 See J ohn S. Nelson, "Argument by Mood in War Movies: Postmodern Ethos in Electronic Media," Argument at Century's End, Thomas A. Hollihan, ed., Annandale, VA, National Communication Association, 2000, pp. 262-269.

6 See Mark Rose, Alien Encounters, Cambridge, MA, Harvard University Press, 1981, pp. 5-95.

7 See Frank Herbert, Dune, New York, Berkley Books, 1965; Ursula K. Le Guin, "Vaster Than Empires and More Slow," Buffalo Gals, and Other Animal Presences, New York, New American Library, 1987, pp. 92-128; Stanislaw Lem, Solaris, J oanna Kilmartin and Steve Cox, trs., New York, Berkley Books, (1961), 1970.

8 Also see Frank Herbert: Dune Messiah, New York, Berkely 
Books, 1969; Children of Dune, New York, Berkley Books, 1976.

9 See Nelson, Tropes of Politics, pp. 150-179.

10 See Azar Nafisi, Reading Lolita in Tehran: A Memoir in Books, New York, Random House, 2003.

11 SeeJ ohn S. Nelson and G. R. Boynton, Video Rhetorics, Urbana, University of Illinois Press, 1997, pp. 195-232.

12 See J ohn S. Nelson, Allan Megill, and D. N. McCloskey, eds., The Rhetoric of the Human Sciences, Madison, University of Wisconsin Press, 1987.

13 See J ohn S. Nelson, "Rhetoric and Its Discontents," Poroi, 2, 2, November, 2003, http://inpress.lib.uiowa.edu/ poroi/papers/ nelson031201.html.

14 J ohn Stuart Mill, Autobiography, Garden City, NY, Doubleday, 1957, p. 42.

15 Ibid., pp. 42-43.

16 Anonymous [J oe Klein], Primary Colors, New York, Warner Books, 1996, p. 1.

17 David V. J . Bell, Power, Influence and Authority, Oxford, Oxford University Press, 1975, p. 10.

18 W. H. Auden, "Shorts," Collected Poems, Edward Mendelson, ed., New York, Random House, 1976, p. 641.

19 See Wendell Berry: The Unsettling of America: Culture and Agriculture, San Francisco, Sierra Club Books, 1977; Home Economics, San Francisco, North Point Press, 1987.

20 Wendell Berry, "The Sycamore," Collected Poems, 1957-1982, San Francisco, North Point Press, 1985, p. 65.

21 J ohn Stuart Mill, On Liberty, David Spitz, ed., NewYork, Norton, (1859), 1975, pp. 2 and 10-11.

22 Mill, Autobiography, p. 64.

23 Wendell Berry, "The Contrariness of the Mad Farmer," Collected Poems, pp. 121-122. 
24 Wendell Berry, "Manifesto: The Mad Farmer Liberation Front," Collected Poems, pp. 151-152.

25 See Deirdre N. McCloskey: "Bourgeois Virtue," American Scholar, 63, 2, Spring, 1994, pp. 177-191; The Vices of Economists and the Virtues of the Bourgeoisie, Amsterdam, Amsterdam University Press, 1996.

26 W. H. Auden, "Shorts," Collected Poems, p. 665. 